\title{
Formulasi Dan Uji Nilai SPF (sun protection factor) Ekstrak Daun Kelor (moringa oliefrea) Dalam Sediaan Tabir Surya Nanoemulsi
}

\author{
Formulation And Test SPF (sun protection factor) Value Of Moringa \\ (moringa oliefera) In Nanoemulsion Sunscreen Preparation \\ ${ }^{1}$ Venny Diah Ningsih, ${ }^{2}$ Sri Nur Atiqah \\ ${ }^{1,2}$ Program Studi Farmasi, Fakultas Ilmu Kesehatan, Universitas Ibrahimy \\ Email: venny.dingsih@gmail.com
}

\begin{abstract}
ABSTRAK
Daun kelor merupakan salah satu bagian tanaman yang memiki banyak khasiat untuk kesehatan salah satunya ialah sebagai antioksidan. Salah satu kandungan daun kelor yang memiliki aktivitas sebagai antioksidan aialah quercetin. Tujuan dari penelitian ini ialah untuk mengetahui nilai SPF yang dihasilkan oleh ekstrak daun kelor yang diformulasikan dalam sediaan nanoemulsi dalam berbagai konsentrasi. Berdasarkan hasil pengujian di dapatkan hasil nilai SPF Pada konsentrasi 10.000 ppm sebesar 5.5, 20.000 ppm sebesar 5.6, dan 30.000 ppm sebesar 5.8.
\end{abstract}

\section{Kata Kunci : Daun Kelor, Konsentrasi, SPF}

\section{ABSTRACT}

Moringa leaves are one part of the plant that has many health benefits, one of which is as an antioxidant. One of the content of Moringa leaves that has activity as an antioxidant is quercetin. The purpose of this study was to determine the SPF value produced by Moringa leaf extract formulated in nanoemulsion preparations in various concentrations. Based on the test results, the SPF value at a concentration of 10,000 ppm is 5.5, 20,000 ppm is 5.6, and 30,000 ppm is 5.8.

Keyword: Moringa Leaf, concentration, SPF

\section{PENDAHULUAN}

Tanaman Kelor (Moringa oliefera)merupakan tanaman yang mudah tumbuh di dataran rendah. Daun kelor sendiri memiliki banyak aktivitas biologis salah satunya ilah sebagai anti oksidan. Kandungan pada pada daun kelor yang memiliki aktivitas sebagai anti oksidan salah satunya ialah quercetin. Dimana menurut Hardianti (2015) kekuatan antioksidan quercetin 4-5 kali lebih besar dibandingkan dengan vitamin $\mathrm{C}$.

$$
\text { Berdasarkan penelitian yang }
$$

dilakukan oleh Rahmat (2009) menyebutkan bahwa dalam setiap 100 gram simplisia basah daun kelor terdapat 384,61 mg quercetin. Dimana berdasarkan hal tersebut tanaman kelor menjadi 
tanaman yang sangat potensial untuk dijadikan suatu produk yang antioksidan yaitu produk tabir surya.

Produk tabir surya adalah produk yang digunakan untuk melindungi kulit dari sengatan sinar matahari. Dimana pada produk tabir surya digunakan nilai SPF (Sun Protection Factor) untuk mengetahui nilai proteksi senyawa aktif terhadap paparan matahari.

Paparan Sinar Matahari (Spektrum UV) terbagi menjadi tiga kelompok berdasarkan panjang gelombang. Panjang gelombang 200-290 nm merupakan sinar UV-C. Panjang gelombang 290-320 nm merupakan sinar UV-B. Panjang gelombang 320-400 nm merupakan sinar UV-A. Tidak semua radiasi sinar UV dari matahari dapat mencapai permukaan bumi. Sinar UV-C yang memiliki energi terbesar tidak dapat mencapai permukaan bumi karena mengalami penyerapan lapisan ozon (Balakhrisnan and Nithya, 2011). Lebih dari $90 \%$ radiasi matahari mencapai bumi adalah UV-A yang berpenetrasi ke dalam menuju epidermis dan dermis pada kulit. UV-A 1000 kali lebih efektif menghasilkan efek tanning (kecoklatan) dibandingkan dengan UV-B. Paparan UVA jangka panjang dapat menyebabkan kulit terbakar dan membahayakan struktur dermis. Hal ini dapat menyebabkan kerusakan protein selular, lipid, dan sakarida kemudian menyebabkan nekrosis dari sel endothel kemudian merusak pembuluh darah di dermal sehingga merubah struktur DNA dan menyebabkan kanker (Balakhrisnan and Nithya, 2011).

Berdasarkan hal tersebut Tujuan Dari peneltian ini ialah ingin mengetahui besaran nilai SPF yang dihasilkan daun kelor dalam beberapa konsentrasi

\section{METODE PENELITIAN}

Alat

Oven (Memmert UN 55), Hotplate and Stirrer (Thermo Scientific), Spektrofotometer Uv-Vis (Thermo Gynesis 150), PSA (Particle Size Analysis) dan Alat Gelas (Iwaki Asahi Glass).

\section{Bahan}

Ekstrak daun kelor, Minyak Zaitun, Tween 80, Propilen Glikol, Metanol, Sudan III, Aquadest

\section{Pembuatan Maserat}

Masing-masing sebanyak 50 gram simplisia daun kelor dimaserasi dengan menggunakan etanol dan methanol (1:10) selam 12 jam dengan pengadukan menggunakan stirrer selama 15 menit. Selanjutnya maserasi (rendaman) disaring menggunakan kertas saring 2 lapis sehingga didapatkan maserat. 


\section{Pembuatan Sediaan Nano Emulsi}

Tabel 1 Formulasi Nanoemulsi Ekstrak Kelor

\begin{tabular}{lcccc}
\hline \multicolumn{1}{c}{ Bahan } & $\mathbf{1 0 . 0 0 0}$ & $\mathbf{2 0 . 0 0 0}$ & $\mathbf{3 0 . 0 0 0}$ & Keterangan \\
\hline Ekstrak Daun Kelor & $1 *$ & 2 & 3 & Bahan Aktif \\
\hline Minyak Zaitun & $5 \%$ & $5 \%$ & $5 \%$ & Fase Minyak \\
\hline Tween 80 & $30 \%$ & $30 \%$ & $30 \%$ & Surfaktan \\
\hline Propilenglikol & $20 \%$ & $20 \%$ & $20 \%$ & Kosurfaktan \\
\hline Alkohol & $1 \%$ & $1 \%$ & $1 \%$ & Pelarut \\
\hline Aquadest & Add 100 & Add 100 & Add 100 & Fase air \\
\hline
\end{tabular}

* dalam satuan gram

Sediaan nanoemulsi Ekstrak

Kelor (Moringa Oliefera) dibuat dengan cara pembentukan emulsifikasi spontan.

Dimana formula campuran fase minyak(minyak zaitun dan simplisia Kelor) dicamprkan dalam fase air (air dan tween 80) dan diaduk dengan kecepatan 1500 rpm selama 30 menit. Hasil menujukkan sediaan nonoemulsi yang jernih yang menandakan sediaan nanoemulsi terbentuk dengan baik (Hendradi et al.,2012)

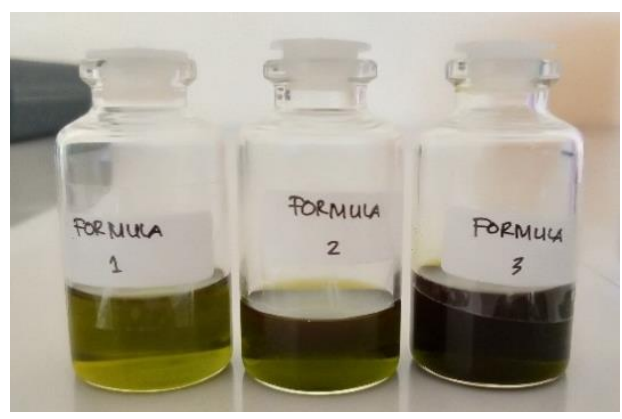

Gambar 1.1 Hasil Pembuatan Nanoemulsi
HASIL DAN PEMBAHASAN

\section{Uji Organoleptik}

Pengujian

organoleptik bertujuan untuk mengetahui karakteristik fisik sediaan nanoemulsi. Organoleptik yang diuji ialah berupa warna bau dan tingkat kelegketan sediaan. Pengujian dilakukan terhadap 34 mahasiswa farmasi. Berdasarkan hasi pengujian terhadap ke 3 formula reponden lebih menyukai formula 2 . Hasil pengujian organoleptik dapat dilihat pada Tabel 2.

Tabel 2 Hasil Uji Organoleptik Sediaan Nanoemulsi

\begin{tabular}{cc}
\hline Formula & Hasil Uji \\
\hline Formula 1 & $\begin{array}{c}\text { Warna hijau bening, bau khas } \\
\text { kelor lemah, tidak lngket } \\
\text { Warna hijau lebih pekat, bau } \\
\text { khas kelor sedikit kuat, tidak } \\
\text { Formula 2 }\end{array}$ \\
lengket \\
Formula 3 & $\begin{array}{c}\text { Warna hijau pekat hampir } \\
\text { kehitaman, bau khas kelor sangat } \\
\text { kuat dan tidak lengket }\end{array}$
\end{tabular}




\section{Uji Ukuran Partikel}

Pengujian ukuran partikel menggunakan PSA (particlel size analyzer). Hasil pengujaian ukuran partikel dapat dilihat pada tabel 3

Tabel 3 Hasil Pengujian Ukuran Partikel

\begin{tabular}{lcc}
\hline \multicolumn{1}{c}{ Formula } & $\begin{array}{c}\text { Ukuran } \\
\text { Partikel* }^{*}\end{array}$ & PDI \\
\hline Formula 1 & $28,85 \mathrm{~nm}$ & 0,2 \\
Formula 2 & $63,9 \mathrm{~nm}$ & 0,1 \\
Formula 3 & $126,2 \mathrm{~nm}$ & 0,003 \\
Standar & $10-100 \mathrm{~nm}$ & $0,2-0,7$ \\
\hline \multicolumn{2}{c}{ Pengujian ukuran } & partikel
\end{tabular}

nanoemulsi bertujuan untuk mengetahui ukuran partikel sediaan dan kesesuainnya dengan standar yang telah ditetapkan.

Menurut (Pathak, 2009) ukuran partikel Nano berkisar antara 10 - 100 nm. Berdasarkan data hasil pengujian ukuran partikel menggunakan particle size analyzer, didapatkan ukuran partikel sediaan nanoemulsi Formula 1 sebesar 28,85 $\mathrm{nm}$ dan Formula 2 sebesar 63,9 $\mathrm{nm}$ termasuk dalam rentang nanopartikel sedangkan Formula 3 sebesar 126,2 tidak termasuk dalam kategori nanoemulsi. Ukuran globul yang kecil menghasilkan sediaan yang jernih dan transparan. Dengan ukuran partikel yang lebih kecil, maka sediaan dapat memberikan efesiensi absorbsi yang tinggi pada berbagai rute pemberian (Handayani et al.,2016).

\section{Uji Tipe Emulsi}

Pengujian tipe emulsi menggunakan zat larut minyak (Sudan III). Zat warna sudan III dicampurkan pada sediaan Nanoemulsi dan kemudian dilihat dibawah mikroskop. Hasil ditunjukkan pada gambar 1.2

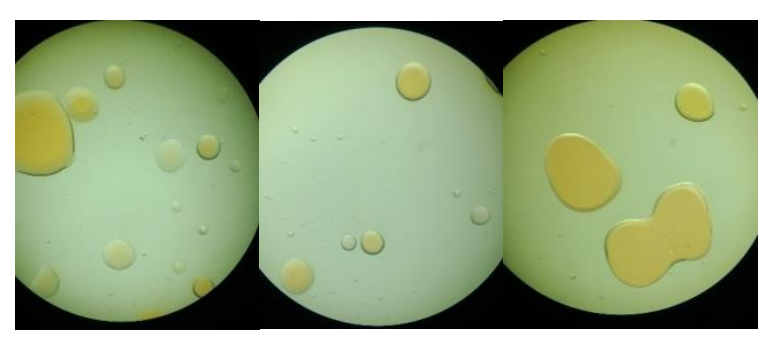

(a) (b)

(c)

Gambar 5.2 Hasil Pengujian Tipe Emulsi (a) Formula 1 (b) Formula 2 (c) Formula 3

Pengujian tipe emulsi dilakukan untuk mengetahui tipe emulsi yang terbentuk. Berdasarkan hasil pengujian menggunakan mikroskop optik menunjukkan bahwa sediaan Nanoemulsi memiliki tipe air dalam minyak $(\mathrm{a} / \mathrm{m})$.

Hal ini dikarenakan zat warna metilen blue yang dicampurkan pada sediaan Nanoemulsi terdispersi merata diseluruh permukaan sediaan Nanoemulsi. Pada formula sediaan nanoemulsi digunakan surfaktan tween 80 dengan fase minyak minyak zaitun. 
Tween 80 bersifat hidrofilik dan konsentrasi minyak dalam sediaan nanoemusi lebih tinggi dibandingkan dengan komposisi air sehingga tipe emulsi yang dihasilkan bersifat air dalam minyak.

\section{Uji Nilai SPF}

Pengujian Nilai SPF (Sun Protector factor) bertujuan untuk mengetahui kemampuan atau aktifitas dari daun kelor dalam melindungi kulit. Pengujian nilai SPF menggunakan spektrofotometer UV-Vis dan diolah menggunakan rumus penentuan SPF

$\mathrm{SPF}=\mathrm{CF} \times \sum_{290}^{320} \mathrm{EE}(\lambda) \times \mathrm{I}(\lambda) \times \operatorname{Abs}(\lambda)$

Keterangan :

CF : Correction Factor (10)

EE : Erythemal effect spectrum

I : Intensitas spektrum matahari pada panjang gelombang

Abs : Absorbansi produk tabir surya

Pengujian hasil SPF dapat dilihat pada tabel 4 :

Tabel 4 hasil Pengujian nilai SPF

\begin{tabular}{ccc}
\hline Formula & Nilai SPF & Jenis Proteksi \\
\hline Formula 1 & 5,5 & Sedang \\
Formula 2 & 5,6 & Sedang \\
Formula 3 & 5,8 & Sedang \\
\hline
\end{tabular}

Berdasarkan hasil perhitungan didapatkan hasil bahwa sediaan nanoemulasi dengan konsentrasi 10.000 ppm didapatkan nilai SPF sebesar 5,5 dengan kategori menutut FDA(Food And Drug Administration) termasuk dalam perlindungan sedang. Pada Formula 2 dengan konsentrasi 20.000 ppm didapatkan nilai SPF sebesar 5,6 dengan kategori menutut FDA termasuk dalam perlindungan sedang. Dan pada formula 3 dengan konsentrasi 30.000 ppm didapatkan nilai SPF sebesar 5,8 dengan kategori menutut FDA termasuk dalam perlindungan sedang. Ketiga formula yang diuji memiliki intensitas perlindungan sedang. Pada hasil SPF dari ketiga formula dapat dilihat bahwa semakin tinggi konsentrasi ekstrak maka nilai SPF yang dohasilkan akan semakin tinggi.

Kulit yang tidak menggunakan tabir surya hanya dapat bertahan 10 menit dibawah paparan sinar matahari, jika kulit menggunakan tabir surya maka ketahanan kulit tersebut diperpanjang 10 kali lipat (Yulianti dkk., 2015). Berdasarkan hal tersebut dapat diambil contoh pada formulai 3 dimana didapatkan nilai SPF sebesar 5,8 lalu dikalikan 10 didapatkan hasil 58 menit. 
Beberapa penelitian menunjukkan bahwa daun kelor (Moringa oleifera) mengandung senyawa antioksidan. Menurut krisnadi (2010), daun kelor mengandung vitamin C dan E yang merupakan snyawa antioksidan. Berdasarkan uji fitokimia daun kelor mengandung tanin, steroid, triterpenoid, flavonoid, saponin, antraquinon, alkaloid dan gula yang rendah (Kasolo dkk., 2010). Beberapa senyawa bioaktif utama yaitu fenoliknya yang merupakan golongan falavonoid. Flavonoid adalah antioksidan yang kuat karena aktivitasnya sebagai antioksidan dan antiinflmasi (Kasolo dkk., 2010). Beberapa flavonoid yang telah diketahui terkandung dalam daun kelor adalah kaemferol, kuersetin, rhamnetin, quercetagetin, dan proantosiandin (Saleem, 1995).

Salah satu flavonoid terbesar yang terkandung dalam daun kelor adalah kuersetin. Kuersetin merupakan antioksidan kuat, dimana kuersetin memiliki kekuatan antioksidan 4-5 kali lebih tinggi dibandingkan dengan vitamin C dan vitamin E (Sutrisno, 2011). Berdasarkan penelitian yang dilakukan oleh rahmat (2009) kandungan kuersetin dalam daun kelor yaitu sebesar 409,06 mg/100 g sampel kering.

\section{SIMPULAN DAN SARAN}

\section{Simpulan}

Berdasarkan pengujian yang telah dilakukan didapatkan hasil bahwa :

1. 3 formula nanoemulsi ekstrak daun kelor yang dibuat memiliki ukuran yang sesuai dalam rentang nanoemulsi

2. Sistem emulsi yang hasilkan ialah system $\mathrm{a} / \mathrm{m}$

3. 3 formula nano emulsi menghasilkan Nilai SPF sedang

\section{Saran}

Untuk penelitian selanjutnya diharapkan mengoptimasi kadar/dosis ekstrak daun kelor sehingga didapatkan nilai SPF yang sesuai dengan ketentuan nilai minimum penggunaan SPF.

\section{DAFTAR PUSTAKA}

Balakhrisnan KP and Narayanaswamyi Nithya.2011. Botanicals as sunscreens: their role in prevention of photoaging and skin cancer. International journal of research in cosmetic science universal research publiations. All right reserved, 2011: 1 (1): 1-12

Hardianti, F. 2015. Pemanfaatan aktivitas antioksidan ekstrak daun kelor (moeinga oliefera) 
dalam sediaan hand body cream. [skripsi]. Jakarta: program studi kimia UIN Syarif Hidayatullah

Rahmat, H. 2009. Identifikasi Senyawa Flavonoid Pada Sayuran Indogenious Jawa Barat [skripsi]. Bogor: Program Teknologi Pertanian Institut Pertanian Bogor

Hendradi, Esti; Purwanti,T Dan Suryanto, Aryco Andy. 2012 Karakterisasi Sediaan Dan Uji Pelepasan Natrium Diklofenak Dengan Sistem Nanoemulsi Dalam Basis Gel HPC-M. Pharmascienta, Vol 1, No 2: 20- 24.

Handayani, S.A; Purwanti, $\mathrm{T}$ dan Erawati, T. 2012. Pelepasan Na-Diklofenak Sistem Niosom Span 20-Kolesterol Dalam Basis Gel HPMC. PharmaScientia, Vol.1, No.2: 32-42.

Kasolo, J.N; Bimeya, G.S; Ojok, L; Ochieng, J dan OkwalOkeng, J.W. 2010. Phytochemical And Uses Moringa Olievera Leaves In Ugandan Rural Communities. Journal of
Medical Plant Research.Vol, 4(9): 753-757

Krisnadi, AD. 2010. Kelor Super Nutrisi. Blora: Pusat Informasi Dan Pengembangan Tanaman Kelor Indonesia

Pathak, Y dan Thassu, D. 2009. Drug delivery nanoparticle formulation and characterization. New York: Informa Helathcare.

Saleem, R. 1995. Studies in the chemical of moringa oleifera lam., and preparation of potentiol biologically significant derivatives of 8 hydroxyquinoline [Repository]. KARACHI: University Of Karachi

Yuliati, Erlina, Adeltrudis Adelsa., Alifia Putri. 2015. Penentuan nilai SPF Ekstrak ETANOL $70 \%$ temu mangga (Curcuma mangga) dan krim ekstrak etanol $70 \%$ temu mangga (curcuma mangga) secara in vitro menggunakan metode spektrofotometri. Majalah kesehatan FKUB. Universitas Brawijaya. Malang 